\title{
Differential hormonal regulation of estrogen receptors $E R \alpha$ and $E R \beta$ and androgen receptor expression in rat efferent ductules
}

\author{
Cleida A Oliveira ${ }^{1,2}$, Germán A B Mahecha ${ }^{2}$, Kay Carnes ${ }^{1}$, Gail S Prins ${ }^{3}$, Philippa T K Saunders $^{4}$, \\ Luiz R França ${ }^{2}$ and Rex A Hess ${ }^{1}$ \\ ${ }^{1}$ Department of Veterinary Biosciences, University of Illinois, 2001 S Lincoln, Urbana, Illinois 61802, USA, \\ ${ }^{2}$ Departments of Morphology and Physiology, Federal University of Minas Gerais, Belo Horizonte-MG, Brazil, \\ ${ }^{3}$ Department of Urology (M/C 955), College of Medicine, University of Illinois, Chicago, Illinois 60612-7310, \\ USA and ${ }^{4}$ MRC Human Reproductive Sciences Unit, University of Edinburgh, Edinburgh EH16 4SB, UK
}

Correspondence should be addressed to R A Hess; Email: rexhess@uiuc.edu

\begin{abstract}
Estrogen receptors, in addition to the androgen receptor (AR), are expressed at high levels in efferent ductules of the male reproductive tract and it is now well recognized that estrogen receptor (ER) $\alpha$ is required for the maintenance of normal structure and function of the ductules. However, little is known regarding the hormonal regulation of the receptors themselves in the male. In the present study, efferent ductule ligation and castration, followed by replacement with testosterone, dihydrotestosterone (DHT) or estradiol was used to investigate the relative importance of circulating and luminal sources of steroid for the modulation of $E R \alpha, E R \beta$ and $A R$ in rat efferent ductules. Uni- or bilateral castration and ligation did not affect the expression of $E R \alpha$ and $E R \beta$, but bilateral castration caused down-regulation of AR. Replacement with DHT and testosterone alone or in combination with estradiol caused the recovery of AR expression to control levels. A slight recovery of AR was also observed after estrogen replacement. ER $\alpha$ expression was decreased to nearly undetectable levels after estrogen replacement. On the other hand, ERß did not show evident effects following any of the treatments, suggesting a constitutive expression of this receptor. This differential modulation of the steroid hormone receptors highlights the importance of maintaining a physiological androgen-estrogen balance to regulate the structure and function of efferent ductules in the male. Reproduction (2004) 128 73-86
\end{abstract}

\section{Introduction}

Androgens have a well-established role in regulating the male reproductive tract. However, studies in several different experimental animal models have revealed that estrogens also play an essential role in the normal structure and function of the male reproductive tract (Lubahn et al. 1993, Smith et al. 1994, Morishima et al. 1995, Hess et al. 1997a, Couse \& Korach 1998, Krege et al. 1998, Fisher et al. 1999, Robertson et al. 1999, Lee et al. 2000, Turner et al. 2000, Atanassova et al. 2001, Oliveira et al. 2001, 2002, Zhou et al. 2001a, Cho et al. 2003). The effects of androgens are mediated through the androgen receptor (AR) and the estrogen actions are mediated through two estrogen receptors, ER $\alpha$ and ERß, which are co-localized in some regions of the male reproductive tract (Nie et al. 2002, Zhou et al. 2002). Despite the known expression of one or both ERs in the male tract (Hess et al. 1997b, Fisher et al. 1997, Nielsen et al. 2001, Saunders et al. 2001,
Nie et al. 2002, Zhou et al. 2002), the full extent of estrogen's action is not completely understood and the interaction of the various steroid receptors in the same cells of the male has not been examined.

Disruption of ER $\alpha$ function caused major effects in the efferent ductules, which resulted in male infertility (Eddy et al. 1996, Hess et al. 1997a, 2001, Oliveira et al. 2001). It is consistent across species that the efferent ductule is the site having the highest concentration of ER $\alpha$ in the male tract (Fisher et al. 1997, Goyal et al. 1997, Hess et al. 1997b, Nielsen et al. 2001, Nie et al. 2002, Zhou et al. 2002). The functional significance of ER $\alpha$ in the efferent ductule is under current scrutiny (Hess et al. 1997a, Lee et al. 2001, Zhou et al. 2001a, Cho et al. 2003), but the regulation of $E R \alpha$ expression itself in the efferent ductules remains to be determined. Even less information is available regarding $E R \beta$, the estrogen receptor subtype with the widest distribution in the male (Hess et al. 1997b, Atanassova et al. 2001, Saunders et al. 2001). Targeted 
disruption of ER $\beta$ ( $\beta E R K O)$ did not promote significant abnormalities in the male reproductive organs (Krege et al. 1998, Dupont et al. 2000); therefore, the biological function of ER $\beta$ in these organs, as well as the factor(s) involved in ER $\beta$ regulation, are at present unknown. It should be emphasized that continued expression of ER $\beta$ in the efferent ductules of the $\alpha E R K O$ was unable to compensate for loss of ER $\alpha$ (Rosenfeld et al. 1998) and the double knockout of ER receptors $(\alpha \beta E R K O)$ resulted in a phenotype resembling that of $\alpha$ ERKO.

The efferent ductules and epididymis have two sources of estrogens and androgens, either the rete testis luminal fluid or the circulating blood in the vasculature. The relative importance of each source of steroid for the efferent ductules is not known (Goyal et al. 1998). However, circulating androgens do not appear to be sufficient to maintain the structure of the initial segment epididymis which is dependent upon luminal dihydrotestosterone (DHT), but do maintain the structure in the corpus and cauda (Fawcett \& Hoffer 1979, Robaire \& Viger 1995). The efferent ductules have high concentrations of AR (Schleicher et al. 1984, Roselli et al. 1991) and bind DHT (Schleicher et al. 1984), but in contrast with the initial segment, there is little or no $5 \alpha$-reductase activity (Roselli et al. 1991) and the testosterone concentration in the luminal fluid $(29 \mathrm{ng} / \mathrm{ml})$ is much higher than that of DHT $(2 \mathrm{ng} / \mathrm{ml}$ ) (Vreeburg 1975). Accordingly, very little androgen dependence has been described for the efferent ductules (Goyal \& Hrudka 1980, Ilio \& Hess 1994, Hess 2002). Considering that efferent ductules express greater amounts of ER than the initial segment of the epididymis (Hess et al. 1997b, Mansour et al. 2001), it is reasonable to suggest that estrogens entering the efferent ductules may play a major role in ductal epithelial function, similar to the role that DHT plays in the initial segment of the epididymis (Robaire \& Viger 1995).

There is little known about the hormonal regulation of the AR and ER in efferent ductules (Ilio \& Hess 1994, Hess 2002, Hess et al. 2002). The only study to have focused on ER regulation in efferent ductules was carried out in the goat (Goyal et al. 1998). That study was based on castration and testosterone replacement, but the authors did not investigate the action of testosterone metabolites, DHT and estradiol, or the regulation of ER $\beta$ expression. Therefore, an investigation of this issue in rodents is warranted. The regulation of $A R$ and $E R$ by androgens and estrogens shows tissue and organ specificity, with both increases and decreases in receptor mRNA and protein in reproductive and non-reproductive tissues, depending on several physiological factors (Barton \& Shapiro 1988, Goyal \& Williams 1988, Quarmby et al. 1990, Lauber et al. 1991, Prins 1992, Gonzalez-Cadavid et al. 1993, Prins \& Birch 1997, Prins et al. 1998, Yeap et al. 1999, Agarwal et al. 2000, Lynch \& Story 2000, Zhu et al. 2000, Turner et al. 2001, Zhou et al. 2001b). These studies reveal the complexity associated with steroid receptor regulation across species, as well as organ- and cell-specific responses (Yeap et al. 1999). Thus, the potential for diverse steroid receptor responses to estrogens and androgens in the efferent ductules would be expected.

The present experiments were designed to investigate whether the expressions of $E R \alpha, E R \beta$ and $A R$ in the rat efferent ductules are regulated by estrogens, androgens or other factors derived from testicular fluid and/or blood. For this purpose, ligation and castration, followed by replacement with testosterone, DHT or estradiol were used. Differential expression of ER $\alpha, E R \beta$ and $A R$ was found in the rat efferent ductules. Estrogen caused down-regulation of $E R \alpha$, and androgens promoted upregulation of $A R$, whereas $E R \beta$ was not affected by these hormones or by the ligation and castration procedures, suggesting a constitutive expression of this receptor in the efferent ductules.

\section{Materials and Methods \\ Animals}

Adult male Sprague-Dawley rats (Harlan Bioproducts, Indianapolis, IN, USA), 90 days old, were used for this study. Upon arrival, the rats were housed under constant conditions of light ( $12 \mathrm{~h}$ light: $12 \mathrm{~h}$ darkness) and temperature $\left(22^{\circ} \mathrm{C}\right)$ and allowed to adapt to the vivarium conditions for at least 7 days before the experiment. They were fed a commercial diet (Teklad Chow-Harlan Teklad, Madison, WI, USA) and tap water was available ad libitum. All animal experiments and surgical procedures were approved by the University of Illinois Division of Animal Resources and were conducted in accordance with the Guide for the Care and Use of Laboratory Animals (1996).

The rats were randomly divided into 13 groups of three animals each, which were subjected to one of the following treatments: unilateral or bilateral ligation, unilateral or bilateral orchidectomy, sham-operation, bilateral orchidectomy followed by daily replacement with different doses of testosterone, DHT or estradiol, or left intact to serve as controls.

\section{Experimental procedures}

The rats were anesthetized with an i.p. injection of sodium pentobarbital $(0.08 \mathrm{ml} / 100 \mathrm{mg}$ body weight $(\mathrm{BW}))$ and surgery was carried out in aseptic conditions. The body weight was recorded before surgery for later comparison with the weight at death. The scrotal skin was shaved and an incision in the mid-line ventral scrotal skin was performed to expose the testis-epididymis, in order to proceed to the ligation and/or castration. With bilateral castration, deprival of both luminal and circulating hormones will be achieved, while ligation and unilateral castration will deprive the efferent ductules of the luminal but not the circulating source of sex hormones. Three animals were not submitted to any treatment and served as intact experimental controls. Sham-operations were 
performed in one group of males to expose, manipulate and then reinsert the testes intact into the scrotum.

\section{Ligation}

After testis-epididymis exposure, the fat surrounding the extratesticular rete testis and the initial part of the efferent ductules was carefully dissected. The ducts were carefully separated from the pampiniform plexus vessels, which were kept intact. Ligation was performed at the extratesticular rete testis level, using a nonabsorbable silk suture placed as close to the testis as possible. For unilateral ligation, the extratesticular rete testis was ligated on one side and the contralateral testis/epididymis was left intact and used as control. After ligation, the testis-epididymis was returned to the scrotum and the scrotal incision was closed by suture. The rats were killed 15 days after ligation.

\section{Castration}

The initial procedure for castration followed the same protocol as that for ligation. The extratesticular rete testis together with the testicular blood vessels were ligated, as close to the testis as possible and then the testes were removed. The ligated efferent ductules and epididymis were placed back into the scrotum and the scrotal incision was closed by suture. When unilateral castration was performed, the contra-lateral testis/epididymis remained intact and served as control. The rats were killed 15 days after castration.

At the end of surgery, the scrotal incision was closed by suture and the wound was treated with Betadine. Postoperative conditions of the animals, including food and water ingestion, defecation, and surgical site were monitored daily.

\section{Hormone replacement}

Starting on the same day as the bilateral orchidectomy, the animals were treated once per day, for 15 days, with s.c. injections of $5 \mathrm{mg} 5 \alpha$-DHT/day (Sigma, St Louis, MO, USA), $1 \mathrm{mg}$ or $5 \mathrm{mg}$ testosterone propionate/day (JT Baker Chemicals, Phillipsburg, NJ, USA), $75 \mu \mathrm{g}$ or $400 \mu \mathrm{g} 17 \beta-$ estradiol-3-benzoate/day (Sigma) or both testosterone propionate $(5 \mathrm{mg} /$ day $)$ and $17 \beta$-estradiol-3-benzoate $(400 \mu \mathrm{g} /$ day), dissolved in a volume of $0.1 \mathrm{ml}$ corn oil as vehicle. The rats were killed after 15 days of treatment. The castration control group received the same volume of vehicle only.

A high dosage of estradiol $(400 \mu \mathrm{g})$ was used because this was found to be effective for inducing complete estrogenization in male rats without inducing significant regression of the efferent ductules (Hansen et al. 1997, Tena-Sempere et al. 2000). The dosage of $75 \mu \mathrm{g}$ estradiol was equivalent to that shown to induce a response in reproductive organs, with minimal histological alterations (Turner et al. 2001). The dose regimen of $1 \mathrm{mg}$ testosterone was used to mimic physiological serum testosterone levels and that of $5 \mathrm{mg}$ testosterone and DHT was based on previous studies showing that this concentration reproduces that which is normally found in the epididymis (Hansen et al. 1997, Fan \& Robaire 1998, Goyal et al. 1998). DHT, the non-aromatizable metabolite of testosterone, was used to get around the problem of whether the potential effects of testosterone were direct or were dependent upon aromatization to estrogen or $5 \alpha$-reduction to DHT.

\section{Tissue preparation and morphometry}

Fifteen days after surgery (ligation or castration) and initiation of hormone replacement, the rats were anesthetized (i.p. sodium pentobarbital $0.1 \mathrm{ml} / 100 \mathrm{~g}$ BW), weighed and perfused intracardially with $10 \%$ neutral buffer formalin (NBF). After fixation, the testis, epididymis with the attached efferent ductules, ventral prostate and seminal vesicles with coagulating glands were removed and weighed. The efferent ductules were dissected out from the epididymis, embedded in paraffin, sectioned $(5 \mu \mathrm{m})$ and mounted on electrostatically charged glass slides. The sections were stained with hematoxylin and eosin for histological study or were used for immunohistochemistry staining. The lumens of the efferent ductules were measured at the widest diameter of five sections of tubules from the proximal area nearest the rete testis. The height of the epithelium of the efferent ductules was measured from the basement membrane to the microvillus bases in areas of straight sections from 25 cells with an evident nucleus. The luminal and epithelial measurements were performed using a calibrated ocular micrometer coupled to a $10 \times$ and $40 \times$ objective, respectively.

\section{Hormone measurements}

Plasma concentrations of testosterone and estradiol were measured by RIA. Blood was collected by cardiac puncture, immediately before death. The plasma was separated by centrifugation and stored at $-20^{\circ} \mathrm{C}$ for subsequent hormone assays. All samples were measured in duplicate. The reported concentrations of the hormones were corrected for extraction losses.

The antibody used for assaying testosterone was developed by Dr O D Sherwood (University of Illinois, Urbana, IL, USA) and the procedures have been described previously (Jackson et al. 1991, Oliveira et al. 2002). For the assay, plasma was extracted with toluene:petroleum ether $(2: 5 \mathrm{v} / \mathrm{v})$. The efficiency of the extraction was $89.7 \%$, the sensitivity of the assay was $0.2 \mathrm{ng} / \mathrm{ml}$ and the assay coefficient of variation was $8.3 \%$.

Estradiol concentration was estimated using a double antibody ultra-sensitive estradiol RIA-DSL 4800 Kit (Diagnostic Systems Laboratories, Inc., Webster, TX, USA). This kit uses an antibody with high affinity for estradiol and low cross-reactivity with other estrogens and with testosterone. For the assay, plasma was extracted with toluene; the efficiency of the extraction was $95.3 \%$. The limit of detection of the assay was $0.8 \mathrm{pg} / \mathrm{ml}$ and the assay coefficient of variation was $10.8 \%$. 


\section{Immunohistochemistry}

Changes in the expression of $E R \alpha, E R \beta$ and $A R$ in the efferent ductules were investigated by immunohistochemistry in all experimental rats, following the protocol previously described (Oliveira et al. 2003). Tissue sections from animals of each experimental group were run in parallel, and the staining was performed in three different sets using one animal of each group per set to confirm the results. Fixed tissues were embedded in paraffin; sections were subjected to microwave antigen retrieval before incubation with primary antibody. The antibodies used were a monoclonal mouse anti-human ER $\alpha$ antibody (NCL-ER-6F11-Novocastra Laboratories, Newcastle, UK), a polyclonal sheep anti-human/rat ER $\beta$ antibody (S-40, raised against a peptide in the hinge domain of hER $\beta$; Saunders et al. 2000) and a polyclonal rabbit anti-rat/human androgen receptor antibody (PG21-29; Prins et al. 1991). Sections were incubated overnight at $4{ }^{\circ} \mathrm{C}$ with diluted primary antibody (1:500 for $E R \alpha$ and $A R ; 1: 1000$ for $E R \beta)$. For negative controls, the sections received PBS in place of the primary antibody. After washing in PBS, the sections were exposed for $1 \mathrm{~h}$ to a biotinylated secondary antibody - goat anti-mouse (for ER $\alpha$ ) (Dako, Carpinteria, CA, USA), rabbit anti-sheep (for ERß) (Vector Laboratories, Burlingame, CA, USA) and goat anti-rabbit (for AR) (Dako), all used at 1:100 dilution. After this step, the sections were incubated with the avidin-biotin complex (Vectastain Elite ABC kit, Vector Laboratories) for $30 \mathrm{~min}$ and the immunoreaction was visualized using diaminobenzidine containing $0.01 \% \mathrm{H}_{2} \mathrm{O}_{2}$ in $0.05 \mathrm{M}$ Tris$\mathrm{HCl}$ buffer, $\mathrm{pH}$ 7.6. Sections stained for ER $\beta$ were slightly counterstained with Mayer's hematoxylin.

\section{Statistical analysis}

A two-way ANOVA was applied to analyze the effect of ligation, castration and hormone replacement on testosterone and estradiol blood concentrations, body weight, efferent ductules/epididymis and accessory sex gland weights, and luminal diameter and epithelial height of efferent ductules. The post hoc Tukey's test was used for multiple comparisons between the experimental groups.

\section{Results}

\section{Hormone levels}

After unilateral castration and efferent ductule ligation on one or both sides, as well as sham operation, testosterone levels did not differ significantly from those of the intact controls, but following bilateral orchidectomy the testosterone concentration fell to a level similar to or below the limit of detection of the assay $(0.2 \mathrm{ng} / \mathrm{ml})($ Table 1$)$. Similar results were observed when corn oil or estradiol was administered following castration. By contrast, supplementation with DHT or testosterone (1 or $5 \mathrm{mg}$ ), alone or combined with estradiol, resulted in plasma testosterone levels significantly higher than controls. This increase in testosterone level was dose dependent, reaching levels above the limit of detection $(20 \mathrm{ng} / \mathrm{ml})$ with the high dose of testosterone $(5 \mathrm{mg})$. Plasma levels of estradiol were not significantly different from intact controls in any experimental group, except after estradiol replacement, alone or combined with testosterone, which resulted in an increase in plasma estradiol to levels above the upper limit of the assay $(>80 \mathrm{pg} / \mathrm{ml})$ (Table 1$)$.

\section{Body and organ weights}

No significant difference in body weight was observed when initial and final weights were compared in most experimental groups, but there was a significant $(P<0.05)$ loss of weight over the 15 days of estradiol replacement (12 to $24 \%$ decrease) (Table 1). Compared with the control group, the weights of the ventral prostate and paired seminal vesicle/coagulating glands, as well as the weight of the efferent ductules/epididymis were significantly diminished

Table 1 Effects of rat efferent ductile ligation, castration and hormonal replacement on plasma testosterone (T) and estradiol (E2) concentrations and on body weight. Values are means \pm S.E.M.

\begin{tabular}{|c|c|c|c|c|}
\hline \multirow[b]{2}{*}{ Treatment } & \multirow[b]{2}{*}{ Testosterone (ng/ml) } & \multirow[b]{2}{*}{ Estradiol (pg/ml) } & \multicolumn{2}{|c|}{ Body weight } \\
\hline & & & Initial (g) & Final (g) \\
\hline Intact control & $3.6 \pm 0.5$ & $17.8 \pm 5.8$ & ND & $396.1 \pm 2.7$ \\
\hline Bilateral ligation & $3.4 \pm 0.8$ & $7.9 \pm 1.3$ & $360.4 \pm 3.2$ & $375.6 \pm 2.4$ \\
\hline Unilateral ligation & $4.2 \pm 0.8$ & $8.1 \pm 2.2$ & $365.9 \pm 8.0$ & $406.3 \pm 9.0$ \\
\hline Unilateral castration & $3.3 \pm 0.2$ & $4.9 \pm 1.1$ & $366.7 \pm 4.4$ & $389.9 \pm 11.0$ \\
\hline Bilateral castration & $0.1 \pm 0.0 *$ & $5.7 \pm 1.5$ & $355.1 \pm 16.0$ & $389.0 \pm 9.2$ \\
\hline Sham operation & $3.3 \pm 0.7$ & $3.9 \pm 0.4$ & $367.5 \pm 3.2$ & $400.2 \pm 12.9$ \\
\hline Bicastration + corn oil (control) & $0.2 \pm 0.0 *$ & $4.9 \pm 1.0$ & $366.0 \pm 5.7$ & $381.9 \pm 1.9$ \\
\hline Bicastration $+\mathrm{T}(1 \mathrm{mg})$ & $10.8 \pm 1.3 *$ & $7.2 \pm 0.4$ & $375.6 \pm 4.0$ & $384.8 \pm 2.4$ \\
\hline Bicastration + T (5 mg) & $>20.0 \pm 0.0 *$ & $6.7 \pm 1.1$ & $381.7 \pm 2.1$ & $393.2 \pm 5.2$ \\
\hline Bicastration + DHT (5 mg) & $10.4 \pm 0.7 *$ & $3.9 \pm 0.2$ & $375.6 \pm 10.4$ & $400.6 \pm 10.7$ \\
\hline Bicastration + E2 $(75 \mu \mathrm{g})$ & $0.2 \pm 0.0^{*}$ & $>80.0 \pm 0.0 *$ & $378.2 \pm 3.2$ & $331.5 \pm 8.8^{*}$ \\
\hline Bicastration + E2 $(400 \mu \mathrm{g})$ & $0.1 \pm 0.0^{*}$ & $>80.0 \pm 0.0 *$ & $372.6 \pm 5.7$ & $284.5 \pm 4.6 *$ \\
\hline Bicastration $+\mathrm{T}(5 \mathrm{mg})+\mathrm{E} 2(400 \mu \mathrm{g})$ & $14.1 \pm 3.4 *$ & $69.0 \pm 8.3 *$ & $372.7 \pm 2.1$ & $319.9 \pm 3.7 *$ \\
\hline
\end{tabular}

$* P \leq 0.05$ compared with intact control; ND, not determined. 
after bilateral castration (Table 2). Estradiol alone was not able to restore the weight of either the accessory sex glands or the efferent ductules/epididymis. Replacement with testosterone or DHT resulted in sex gland weights even higher than intact controls (Table 2). Although androgen treatment greatly increased the weight of the efferent ductules/epididymis, they were still below the intact control weight. On the other hand, when testosterone was combined with estradiol, the efferent ductules/epididymis weight was restored to control levels. Combined testosterone and estrogen also resulted in heavier sex glands than those treated with testosterone alone. Unilateral castration and unior bilateral ligation, as well as sham operation, did not affect significantly the weight of the accessory glands (Table 2). Similarly, the weight of the efferent ductules/epididymis was not greatly affected by sham operation, but a significant decrease in weight at the operated side was observed when unilateral ligation (32\%) and unilateral castration $(28 \%)$ were compared with the contra-lateral intact efferent ductules/epididymis, or when the bilateral ligated $(18-22 \%)$ was compared with the intact control (Table 2).

\section{Epithelial cell height}

Regression of the efferent ductules, characterized by a reduction in luminal diameter and epithelial height, was observed as a result of either ligation or castration, but the effects on luminal diameter were more dramatic (Fig. 1). Efferent ductule luminal diameter was significantly increased by $400 \mu \mathrm{g}$ estradiol, when compared with castrated control animals, but androgens had no effect. In contrast, testosterone and DHT replacement, as well as estradiol, caused a partial recovery in the height of the epithelium, but higher epithelium was seen after resupplementation with testosterone plus estradiol. However, in all cases the epithelial height was still below the control level.

\section{Expression of androgen receptors}

The AR expression in control efferent ductules was found in the nuclei of ciliated and nonciliated epithelial cells, in addition to the peritubular and some stromal cells (Fig. 2A). Similarly, the initial segment of the epididymis was strongly positive for AR in the epithelial, peritubular and stromal cell nuclei. AR expression was not affected by sham operation, unilateral or bilateral ligation, or unilateral castration. On the other hand, bilateral castration caused a remarkable down-regulation in AR protein expression (Fig. 2B). Testosterone, alone or associated with estradiol, as well as DHT restored the AR to the intact control levels (Fig. 2C-F). The AR immunostaining intensity in the efferent ductules was partially restored by estradiol supplementation (Fig. 2G, H). The effects on AR expression in the initial segment were similar to those of the efferent ductule, including the recovery of staining after estradiol replacement (Fig. 2I-L).

\section{Expression of ERa}

Immunohistochemical localization of ER $\alpha$ in the efferent ductules was restricted to the ciliated and nonciliated cell nuclei (Fig. 3A). ER $\alpha$ immunostaining in the efferent ductules after unilateral or bilateral ligation and castration was unchanged when compared with that of intact controls (Fig. 3B). The administration of corn oil, testosterone and DHT following castration had no effect on ER $\alpha$ expression (Fig. 3C, D, E). However, ER $\alpha$ was greatly reduced in the epithelium of the efferent ductules after estradiol replacement, in a dose-dependent manner (Fig. 3G, H). The higher dose of estradiol $(400 \mu \mathrm{g})$ promoted down-regulation of $\mathrm{ER} \alpha$ to nearly undetectable levels, both when used alone and in combination with testosterone (Fig. 3F, H). The lower dose of estradiol $(75 \mu \mathrm{g})$ caused less, but still a dramatic, reduction in immunodetectable ER $\alpha$ in the efferent ductules (Fig. 3G). The initial segment of the epididymis

Table 2 Effects of efferent ductile ligation, castration and hormonal replacement on the weights of the efferent ductile/epididymis, ventral prostate, and combined seminal vesicles (SV)/coagulating glands (CG) in the rat. Values are means \pm S.E.M.

\begin{tabular}{|c|c|c|c|c|}
\hline \multirow[b]{2}{*}{ Treatment } & \multicolumn{2}{|c|}{ Efferent ductules + epididymis } & \multirow{2}{*}{$\begin{array}{c}\text { Ventral prostate } \\
(\mathrm{mg} / 100 \mathrm{~g} \mathrm{BW})\end{array}$} & \multirow{2}{*}{$\begin{array}{c}\text { SV + CG } \\
(\mathrm{mg} / 100 \mathrm{~g} \mathrm{BW})\end{array}$} \\
\hline & Left (mg) & Right (mg) & & \\
\hline Intact control & $170.6 \pm 4.7$ & $170.0 \pm 2.8$ & $257.1 \pm 8.0$ & $481.1 \pm 24.0$ \\
\hline Bilateral ligation & $133.3 \pm 2.7 *$ & $136.7 \pm 4.8 *$ & $172.6 \pm 16.3$ & $428.3 \pm 35.7$ \\
\hline Unilateral ligation & $161.6 \pm 5.8$ & $110.6 \pm 5.9 * *$ & $203.1 \pm 11.1$ & $398.8 \pm 20.3$ \\
\hline Unilateral castration & $169.5 \pm 9.4$ & $122.9 \pm 5.5^{* *}$ & $252.9 \pm 35.8$ & $464.2 \pm 18.1$ \\
\hline Bilateral castration & $55.4 \pm 0.9 *$ & $60.3 \pm 3.2 *$ & $26.3 \pm 1.2 *$ & $67.7 \pm 4.3 *$ \\
\hline Sham operation & $187.8 \pm 10.9$ & $161.5 \pm 17.8$ & $196.9 \pm 27.2$ & $440.5 \pm 14.4$ \\
\hline Bicastration + corn oil (control) & $56.8 \pm 0.2 *$ & $56.6 \pm 5.7 *$ & $25.0 \pm 0.7 *$ & $74.8 \pm 2.9 *$ \\
\hline Bicastration + T (1 mg) & $148.4 \pm 2.9 *$ & $148.8 \pm 4.9 *$ & $348.7 \pm 38.6^{*}$ & $950.2 \pm 33.0 *$ \\
\hline Bicastration + T (5 mg) & $147.5 \pm 10.8 *$ & $147.5 \pm 13.2 *$ & $379.6 \pm 11.3 *$ & $929.2 \pm 3.2 *$ \\
\hline Bicastration + DHT (5 mg) & $147.1 \pm 11.9 *$ & $142.8 \pm 8.2 *$ & $362.4 \pm 19.4 *$ & $866.8 \pm 10.8^{*}$ \\
\hline Bicastration + E2 $(75 \mu \mathrm{g})$ & $63.8 \pm 4.2 *$ & $81.7 \pm 13.7 *$ & $42.5 \pm 3.6 *$ & $103.2 \pm 15.5^{*}$ \\
\hline Bicastration + E2 $(400 \mu \mathrm{g})$ & $69.1 \pm 7.6 *$ & $90.7 \pm 18.5^{*}$ & $51.0 \pm 9.4 *$ & $104.6 \pm 9.0 *$ \\
\hline Bicastration + T $(5 \mathrm{mg})+\mathrm{E} 2(400 \mu \mathrm{g})$ & $157.6 \pm 4.5$ & $169.8 \pm 5.1$ & $466.8 \pm 18.5^{*}$ & $1206.9 \pm 56.7 *$ \\
\hline
\end{tabular}

T, testosterone; E2, $17 \beta$-estradiol.

$* P \leq 0.05$ compared with intact control; **P $\leq 0.05$ compared with castrated control. 


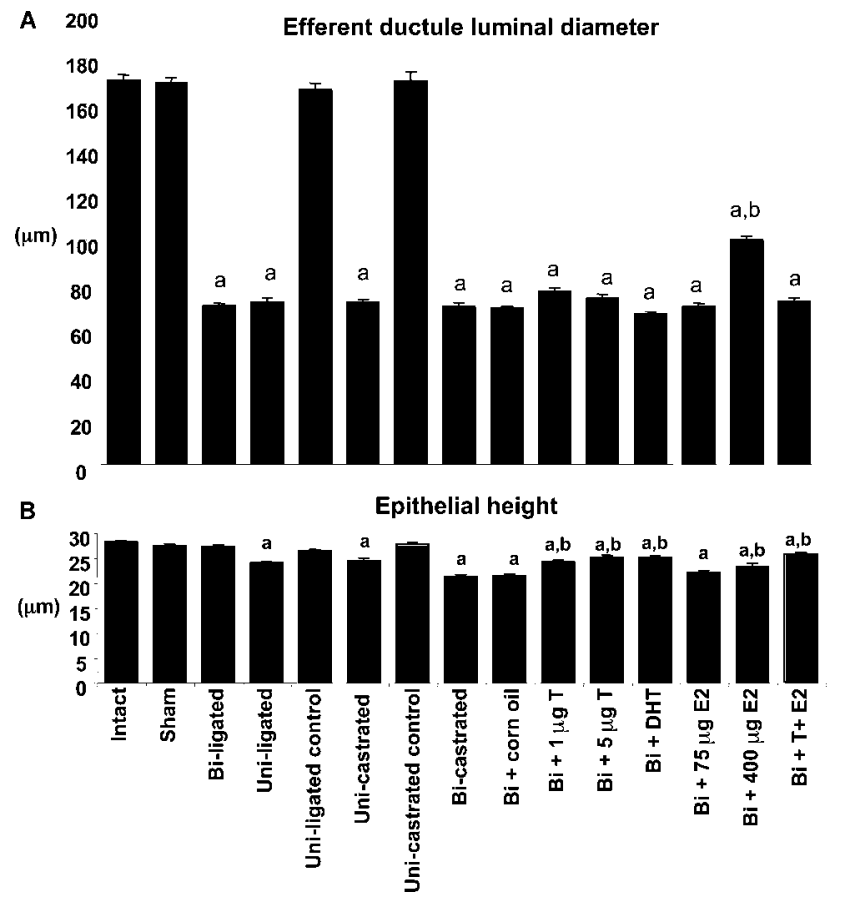

Figure 1 Effects of ligation, castration and hormone replacement on the efferent ductule. (A) Compared with the intact rat, the luminal diameter of the efferent ductule was significantly (a) decreased in ligated and castrated rats, following or not hormone replacement. However, compared with the castrated control animal, the luminal diameter was significantly (b) higher after treatment with the high dose of estradiol (E2; $400 \mu \mathrm{g})$. (B) The height of the epithelium decreased significantly (a) after unilateral ligation or castration followed or not by hormone replacement. Testosterone ( $\mathrm{T} ; 1 \mathrm{mg}$ and $5 \mathrm{mg}), \mathrm{DHT}(5 \mathrm{mg})$ and estradiol $(75 \mu \mathrm{g}$ and $400 \mu \mathrm{g})$ caused a partial recovery of the epithelial height, compared with the castrated rat. Higher epithelium was seen after replacement with testosterone $(5 \mathrm{mg})+$ estradiol $(400 \mu \mathrm{g})$. Values represent means \pm S.E.M. ( $n=3$ in each group). a, $P \leq 0.05$ compared with intact rat; $b, P \leq 0.05$ compared with castrated rat. Uni, unilateral; $\mathrm{Bi}$, bilateral.

was negative for $\mathrm{ER} \alpha$ (Fig. 3l); however resupplementation with estradiol induced slight $\mathrm{ER} \alpha$ immunoexpression in the epithelium (Fig. 3J).

\section{Expression of ERB}

The pattern of ER $\beta$ localization in efferent ductules and initial segment was similar to that of the $A R$, with positive staining detected in the nuclei of epithelial cells, as well as in peritubular and some stromal cells (Fig. 4A). Bilateral and unilateral ligation or castration, as well as hormonal replacement did not change ER $\beta$ expression or, at the very least, caused a very slight decrease in ERß (Fig. 4B-H). A decrease in staining was observed after testosterone treatment.

\section{Discussion}

This study provided evidence that expression of $E R \alpha, E R \beta$ and $A R$ proteins in the rat efferent ductules is differentially regulated by androgens and estrogens. These results partially differed from those in the goat (Goyal et al. 1998), but agree with recent findings that $A R$ and both ERs respond differently to the antiestrogen ICI 182,780, with $E R \alpha$ expression being dramatically down-regulated, but $E R \beta$ and $A R$ levels remaining unchanged in the rat efferent ductule (Oliveira et al. 2003). These data suggest that there may be important interspecies differences in the regulation of ER expression in the male reproductive tract.

The effects of castration and hormone replacement on body and sex gland weight, and blood concentrations of testosterone and estradiol were similar to previously reported data for the rat (Podesta et al. 1975, Roselli \& Resko 1984). The effects of androgens on sex gland weight, which was much higher than controls, was expected because a high supplemental dose of hormone was used to maintain the elevated concentrations needed to stimulate the testis-epididymal region. The rat efferent ductule epithelium regressed and the efferent ductule/epididymal weight decreased following castration, and both parameters were restored by androgens but not to control levels. Circulating estrogen alone does not appear to be sufficient to maintain the efferent ductule structure. However, concomitant administration of testosterone and estradiol was the only treatment able to restore efferent ductule/epididymal weight to the control level and induced a higher recovery of epithelial height, indicating that a cooperative action of these steroids may be necessary.

The effects of androgens on AR expression in the efferent ductule are in agreement with previous studies showing increased AR protein following testosterone or DHT treatment (Calandra et al. 1975, Sar et al. 1990, Goyal et al. 1998, Yeap et al. 1999, Zhu et al. 2000, Turner et al. 2001). Others have shown up-regulation of AR protein even in the presence of decreased mRNA (Quarmby et al. 1990, Yeap et al. 1999). These data indicate that the mechanism underlying $A R$ regulation by androgens involves differential transcriptional and/or post-transcriptional events, which will likely be cell- and tissue-specific (Yeap et al. 1999). In this sense, recent findings in the prostate gland showed that $A R$ is down-regulated by androgen withdrawal as well as estrogen treatment, through a post-transcriptional pathway mediated by proteasome (Woodham et al. 2003). In the present study, ligation of the efferent ductule did not affect levels of immunodetectable AR, nor did unilateral castration. Taken together, these data indicate that deprivation of circulating androgens, but not of luminal androgens or other testicular factors such as androgen binding protein (ABP), affected AR expression, suggesting that AR expression in rat efferent ductules is mainly dependent on circulating androgens. This result is in agreement with that found for efferent ductules in the goat (Goyal et al. 1998). ABP is a Sertoli cell product important for the maintenance of high levels of intratubular androgen (Danzo et al. 1977, Dohle et al. 2003). Some chemical agents that alter $A R$ 


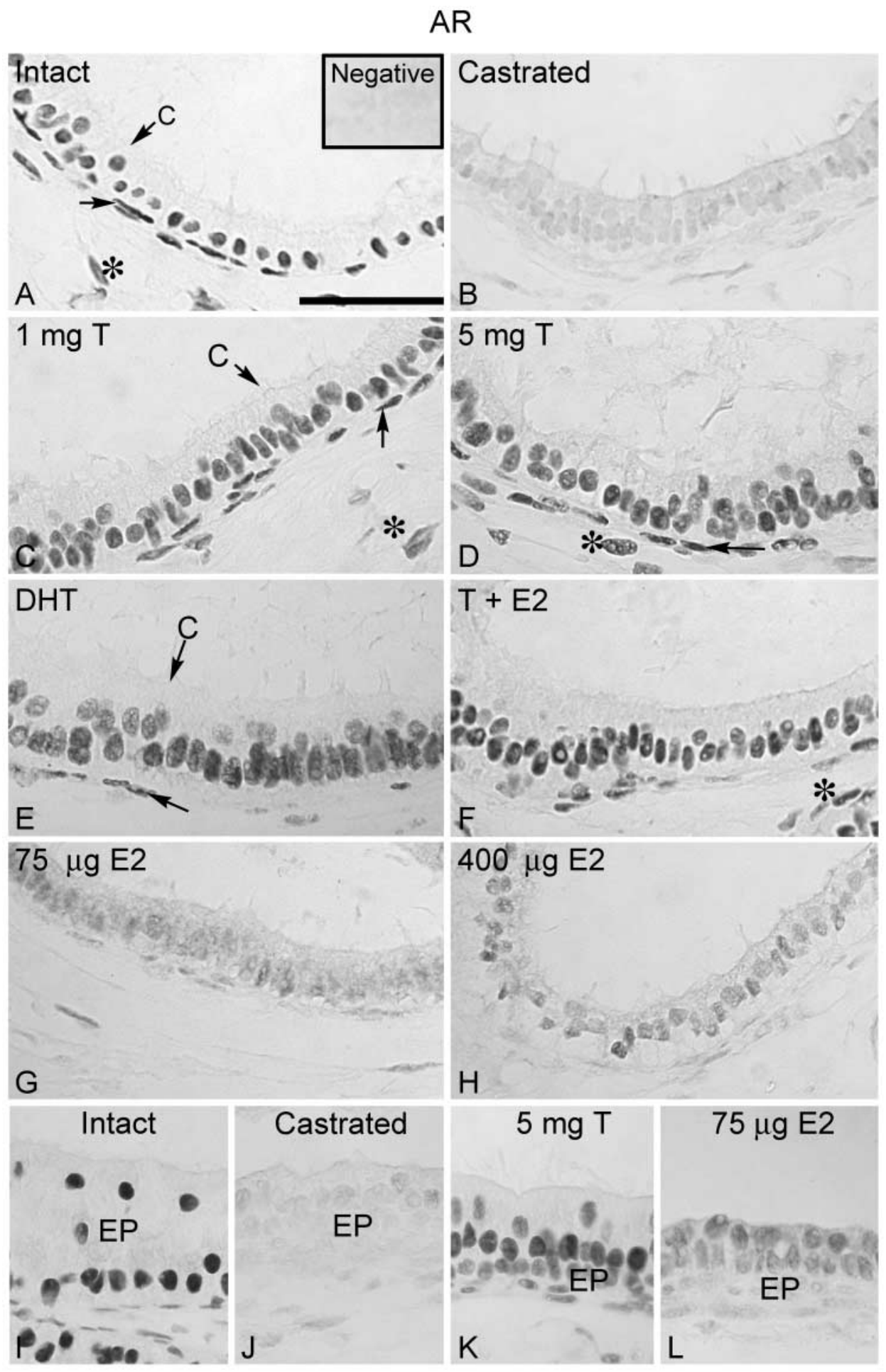

Figure 2 Regulation of AR in the efferent ductule of rat. (A) AR was intensely expressed in the nuclei of the efferent ductule epithelial, peritubular (arrow) and some stromal cells $(*)$ of intact control rats. C, ciliated cell. Insert represents the negative control. (B) After castration, there was a dramatic decrease in the AR expression in the efferent ductule. Replacement with (C) $1 \mathrm{mg}$ testosterone (T), (D) $5 \mathrm{mg}$ testosterone, (E) $5 \mathrm{mg}$ DHT, as well as (F) $5 \mathrm{mg}$ testosterone associated with $400 \mu \mathrm{g}$ estradiol (E2) restored AR immunostaining to the control levels. A slight recovery of AR staining was observed after estradiol $(75 \mu \mathrm{g}$ and $400 \mu \mathrm{g}$ ) replacement in the efferent ductules $(\mathrm{G}, \mathrm{H})$. The initial segment of the epididymis (EP) was positive for AR (I). The AR staining decreased after castration (J), but testosterone replacement restored the positive reaction (K). Estradiol replacement also induced a slight recovery of AR staining in the initial segment (L). The results regarding the efferent ductule of sham-operated, unilateral or bilateral ligated and unilateral castrated rats were similar to those of intact controls (not shown). Bar $=100 \mu \mathrm{m}$. 


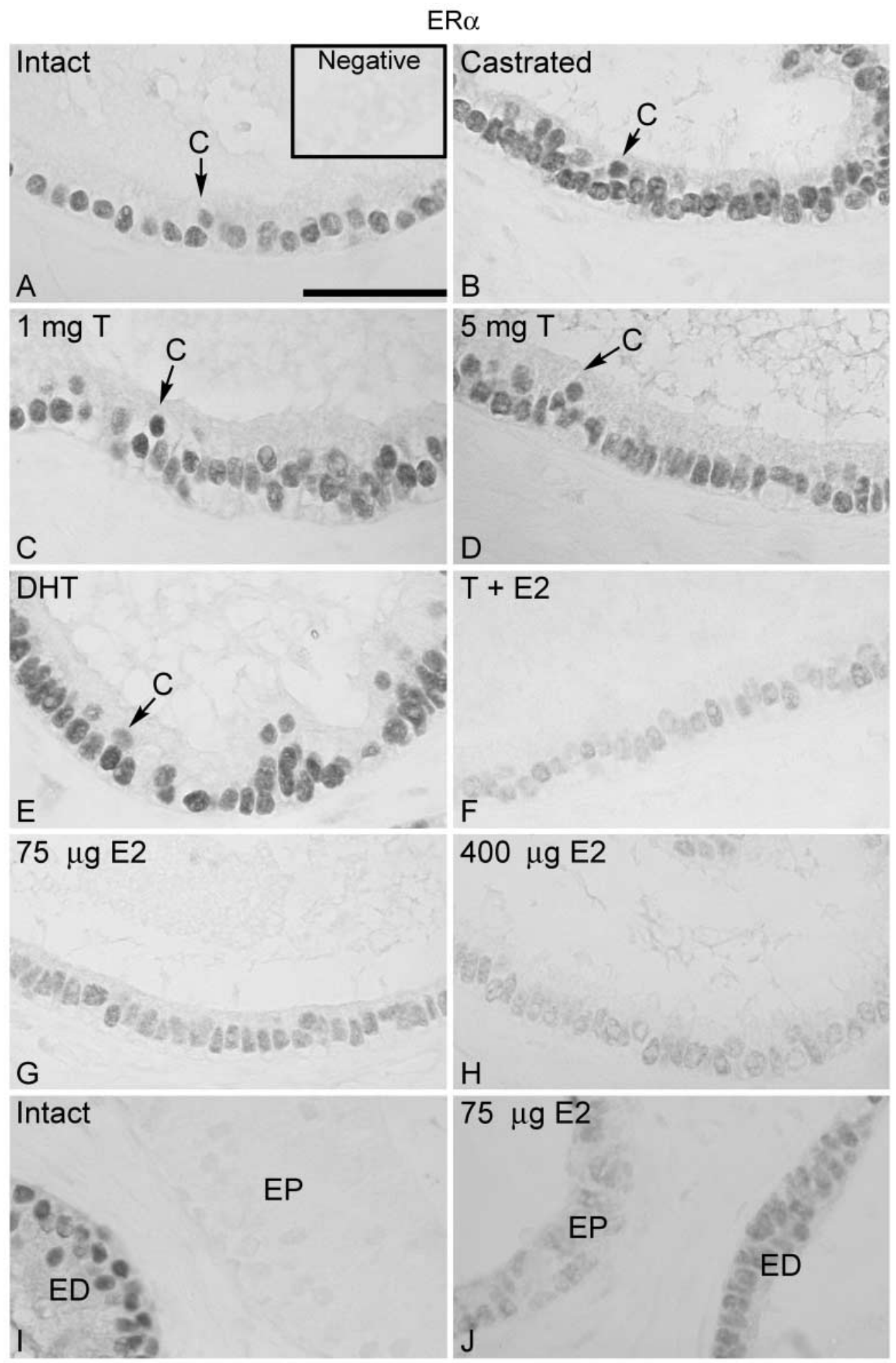

Figure 3 Regulation of ER $\alpha$ in the efferent ductule of the rat. (A) ER $\alpha$ was expressed in the nuclei of the ciliated (C) and nonciliated cells of efferent ductule epithelium in intact control rats. Insert represents the negative control. Castration (B) or castration followed by androgen replacement (C, D, E) did not affect ER $\alpha$ expression. After replacement with $400 \mu \mathrm{g}$ estradiol (E2) associated with $5 \mathrm{mg}$ testosterone (T) (F), or with estradiol $(75 \mu \mathrm{g}$ and $400 \mu \mathrm{g})$ alone $(\mathrm{G}, \mathrm{H})$ there was a remarkable decrease in ER $\alpha$ expression. The higher dose of estradiol induced a greater decrease in $E R \alpha(F, H)$. (I) The initial segment of the epididymis (EP) was negative for ER $\alpha$ in control animals. ED, distal efferent ductules. (J) After replacement with estradiol $(75 \mu \mathrm{g}$ and $400 \mu \mathrm{g})$ a slight staining for ER $\alpha$ was found in the initial segment epithelium (EP). The results from efferent ductules of sham-operated, unilateral or bilateral ligated and unilateral castrated rats were similar to those of intact controls (not shown). Bar $=100 \mu \mathrm{m}$. 


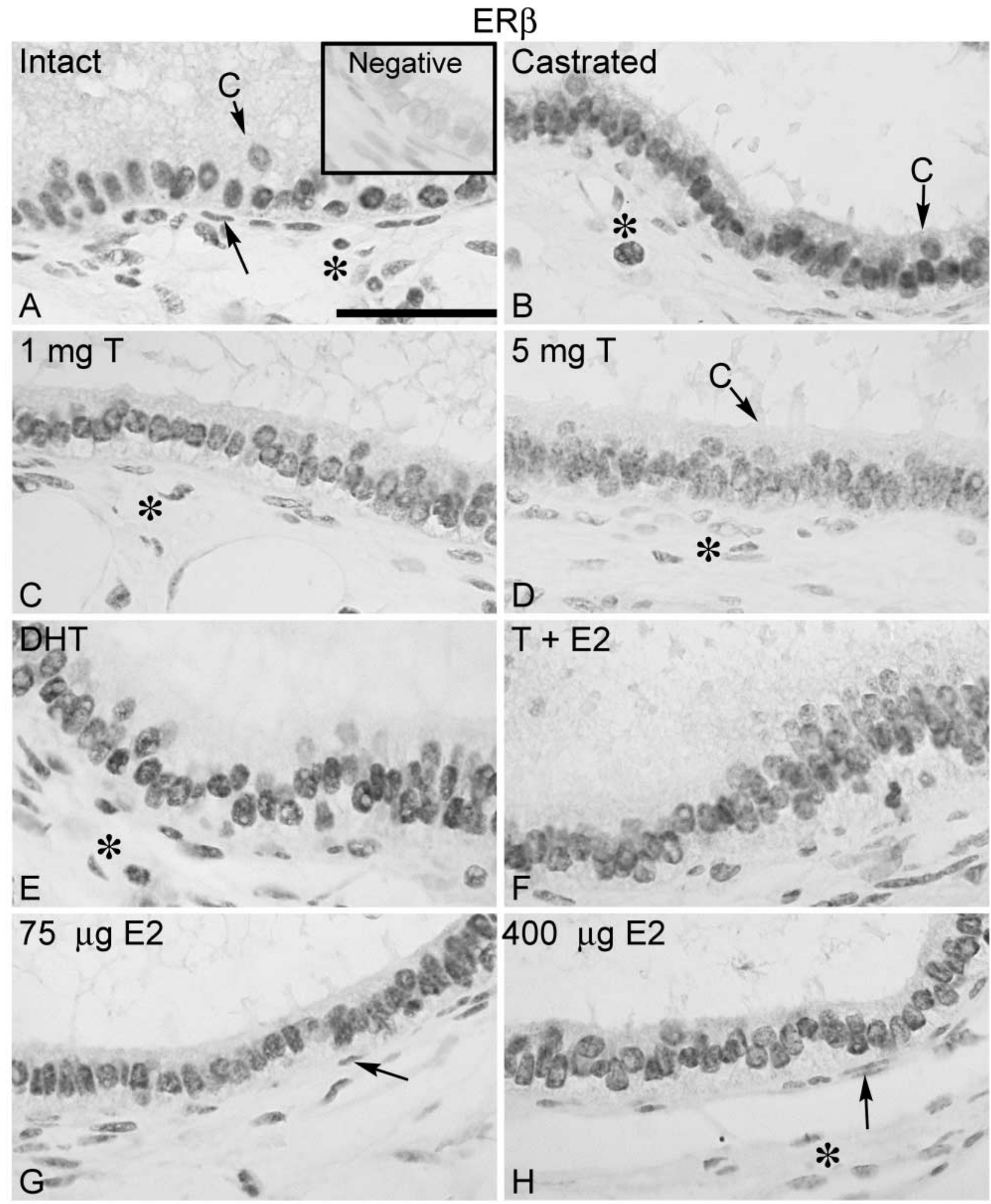

Figure 4 Regulation of $E R \beta$ in the efferent ductule of the rat. (A) $E R \beta$ was expressed in the nuclei of the efferent ductule epithelium, peritubular (arrow) and some stromal cells $(*)$ in intact control rats. C, ciliated cells. Insert represents the negative control. Castration (B) or castration followed by replacement with $5 \mathrm{mg}$ testosterone (T) (C, D), $5 \mathrm{mg}$ DHT (E), $400 \mu \mathrm{g}$ estradiol (E2) associated with $5 \mathrm{mg}$ testosterone (F) or with estradiol alone $(75 \mu \mathrm{g}$ and $400 \mu \mathrm{g})(\mathrm{G}, \mathrm{H})$ did not cause evident effects in ER $\beta$ expression, except for a slight decrease in staining in some areas after testosterone replacement $(\mathrm{D})$. The results from efferent ductules of unilateral or bilateral ligated and unilateral castrated rats were similar to those of bilateral castrated rats (not shown). Bar $=100 \mu \mathrm{m}$. 
expression in the testis also alter the expression of $\mathrm{ABP}$ (Tirado et al. 2004). Altered expression of ABP has been associated with testis and male tract alterations similar to those caused by alterations of AR (Danzo et al. 1977, Jeyaraj et al. 2002). Therefore, it would be possible that ABP could have some effect on AR expression. We cannot exclude this possibilitiy, but ABP transgenic mice showed no significant changes in androgen receptor, which may indicate that the deleterious effects of aberrant levels of ABP may be caused by some other factor than AR modulation (Munell et al. 2002).

It was interesting to note that estrogen replacement also caused a partial recovery of AR expression in the efferent ductule following castration. Modulation of AR by estrogen has been reported in the rat testis (Turner et al. 2001) and in some areas of the rat brain (Lynch \& Story 2000). In the prostate, developmental estrogenization has been shown to induce a transient up-regulation of $E R \alpha$ and a down-regulation of $A R$ and $E R \beta$ levels in adult prostate epithelium (Prins \& Birch 1997, Prins et al. 2001). Estrogen also appears to interfere in some physiological events usually attributed to androgens, such as modulation of prostate androgen responsive genes (prostate specific androgen (PSA), Rosner et al. 1998; C3 and sulphated glycoprotein-2 (SGP-2), Turner et al. 2001) and stimulation of spermatogenesis in hypogonadal males (Ebling et al. 2000), suggesting that the effects of estradiol are mediated via cross-reactivity with AR. Physical interactions between $A R$ and $E R \alpha$, which result in estradiol-induced modulation of AR transcriptional activity by ER $\alpha$ (Panet-Raymond et al. 2000) and the ability of estradiol to activate AR genes when AR complexes with the coactivator ARA70 (Yeh et al. 1998) or with sex hormone binding globulin (SHBG)-SHBG receptor (Rosner et al. 1998), have been described and they indicate alternative pathways to explain receptor interplay. It is more likely that interaction between androgen and estrogen action may exist in the male reproductive tract, similar to other tissues (Migliaccio et al. 2000, Ochiai et al. 2004).

The distribution of $\mathrm{ER} \alpha$ was found to be restricted to the epithelium of the efferent ductules, consistent with findings across species investigated to date (Hess 2003). The only dramatic decrease in ER $\alpha$ expression in the efferent ductules was observed after estrogen replacement. ER $\alpha$ down-regulation by estradiol was dose dependent, confirming previous findings that $E R \alpha$ proteolysis is modulated by ligand concentration (Preisler-Mashek et al. 2002). Both ligation and castration were unable to disturb $E R \alpha$ expression in the efferent ductules. Because plasma levels of estradiol were not altered significantly by these procedures, it would appear that circulating estradiol might play a role in regulating ER $\alpha$ in the efferent ductule epithelium. Considering that aromatase mRNA was recently detected in the epithelium of epididymal cells in vitro (Wiszniewska 2002), the contribution of locally produced estrogen cannot be ruled out. However, it is important to point out that studies in several species have detected aromatase protein and activity in the sperm that traverse the male tract, but not in the epithelium of the ductal system (Janulis et al. 1996, 1998).

The efferent ductule is the segment of the male tract more sensitive to altered levels of estrogen or disruption of estrogen action, as shown by experiments using high doses of estrogens, antiestrogens, as well as knockout of estrogen receptors, all of them resulting in efferent ductule abnormalities, especially in the luminal diameter (Hess et al. 2002, Oliveira et al. 2001, 2002, Rivas et al. 2002, 2003, Cho et al. 2003). Also in the present study, estrogen $(400 \mu \mathrm{g})$ was the treatment that caused greater dilation in the efferent ductules after castration. These results are in agreement with recent data showing that the primary function of estrogens/ER $\alpha$ in the efferent ductules is to regulate the expression of proteins involved in fluid reabsorption (Zhou et al. 2001a, Lee et al. 2001, Oliveira et al. 2002), in addition to the maintenance of the epithelial morphology (Hess 2003), although the last function appears to be more dependent on an androgen-estrogen balance (Rivas et al. 2003).

In contrast to the effects on efferent ductules, estrogen replacement induced a weak expression of $E R \alpha$ in the initial segment of the epididymis, a region that was negative for $E R \alpha$ in the control animals. Depending on the tissue and the antibodies used, estrogens have been shown to cause autologous ER up-regulation in some tissues (liver, Barton \& Shapiro 1988; prostate epithelium, Prins \& Birch 1997; uterus, Zou \& Ing 1998; bone, Zhou et al. 2001 b; thyroid, Banu et al. 2002). Considering that in most of these tissues ER $\alpha$ expression is usually low, it is possible that the difference between ER $\alpha$ expression in response to estrogen may be determined by the relative levels of expression of this receptor. In sites where ER $\alpha$ is abundant, such as the efferent ductule, it appears that down-regulation of $E R \alpha$ is the mechanism responsible for regulating the duration of physiological response to the activating ligand. On the other hand, in sites with low abundance or no ER $\alpha$ expression there is a likelihood that estrogens will up-regulate $E R \alpha$.

Differing from $A R$ and $E R \alpha$, there was no dramatic effect on the ER $\beta$ expression in efferent ductules after any treatment presently investigated. Similar to the present result, ER $\beta$ immunoreaction was not affected by androgen/estrogen withdrawal or by steroid replacement in rat testis and prostate (Turner et al. 2001). Also, exposure of rats to the phytoestrogen genistein (Cotroneo et al. 2001) and diethylstilbestrol (Atanassova et al. 2001, McKinnell et al. 2001) caused an alteration in ER $\alpha$ expression, but not $E R \beta$, in the female and male tract respectively. However, in contrast to the efferent ductules, ER $\beta$ mRNA may be regulated by androgens in the prostate. Castration down-regulates ER $\beta$ mRNA in the prostate, and testosterone restores it (Prins et al. 1998, 2001, Shughrue et al. 1998).

The antiestrogen ICI 182,780 also has no effect on ER $\beta$, although it leads to a dramatic down-regulation of $E R \alpha$ in 
the rat efferent ductules (Oliveira et al. 2003). In agreement with these results, target disruption of ER $\beta$ has failed to cause major abnormalities in the male reproductive tract (Krege et al. 1998). Given the widespread expression of ER $\beta$ along the male reproductive tract, this lack of response to ligation, castration or hormonal modulation may be indicative that $E R \beta$ has a constitutive expression and a non-essential function in the male tract. Another possibility is that the factor that regulates $E R \beta$ is most likely of extra-testicular origin. A plausible candidate for regulation of $E R \beta$ in the efferent ductules would be luteinizing hormone (LH). It has already been shown that $\mathrm{LH}$ receptors (LHR) are present in the male tract (Derecka et al. 1999), and that there are correlations between ER $\beta$ and LH/LHR concentrations (Bao et al. 2000, Guo et al. 2001).

Using a similar experimental approach to the present one, Goyal et al. (1998) did not find any difference in the regulation of $A R$ and $E R$ in the efferent ductule of the goat. In the goat, both receptors appeared to be regulated by circulating androgens. However, it is necessary to highlight the fact that ER subtypes were not differentiated in that study, nor was the regulatory effect of estrogen and DHT investigated. In addition, other studies have shown differences in sex steroid receptor expression and steroid hormone action along the female reproductive tract between ruminants and other mammals (Miller et al. 1979, Stone et al. 1982), pointing to species differences in $E R$ regulation. Differences in ER distribution in the male tract of rat and goat can be exemplified by the negative staining of goat efferent ductule ciliated cells and Leydig cells in the testis, both of them being positive for ERs in the rat. Confirming that diverging results may be attributed to species differences, to date the only species showing agonist uterotropic action for the antiestrogen ICI 182,780 is the ewe (al-Matubsi et al. 1998), in contrast to rat, mice, pig, monkey and human (Wakeling et al. 1991, Dukes et al. 1993, Thomas et al. 1994, Branham et al. 1996, Tarleton et al. 1999).

In conclusion, the present observations indicate that $E R \alpha, E R \beta$ and $A R$ are differentially regulated in the efferent ductule, where AR and $E R \alpha$ are selectively modulated by their own ligand, but ER $\beta$ appears to be constitutively expressed. The potential for multiple factors to be regulating the expression of several steroid hormone receptors in some cells, highlights the importance of maintaining a physiological androgen and estrogen balance to regulate the structure and function of efferent ductules in the male.

\section{Acknowledgements}

This work was supported in part by NIH Grant HD-35126 (to

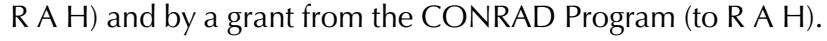

\section{References}

Agarwal VR, Sinton CM, Liang C, Fisher C, German DC \& Simpson ER 2000 Upregulation of estrogen receptors in the forebrain of aromatase knockout (ARKO) mice. Molecular and Cellular Endocrinology 162 9-16.

Atanassova N, McKinnell C, Williams K, Turner KJ, Fisher JS Saunders PT, Millar MR \& Sharpe RM 2001 Age-, cell- and regionspecific immunoexpression of estrogen receptor alpha (but not estrogen receptor beta) during postnatal development of the epididymis and vas deferens of the rat and disruption of this pattern by neonatal treatment with diethylstilbestrol. Endocrinology 142 874-886.

Banu SK, Govindarajulu P \& Aruldhas MM 2002 Testosterone and estradiol up-regulate androgen and estrogen receptors in immature and adult rat thyroid glands in vivo. Steroids 67 1007-1014.

Bao B, Kumar N, Karp RM, Garverick HA \& Sundaram K 2000 Estrogen receptor-beta expression in relation to the expression of luteinizing hormone receptor and cytochrome p450 enzymes in rat ovarian follicles. Biology of Reproduction 63 1747-1755.

Barton MC \& Shapiro DJ 1988 Transient administration of estradiol17 beta establishes an autoregulatory loop permanently inducing estrogen receptor mRNA. PNAS 85 7119-7123.

Branham WS, Fishman R, Streck RD, Medlock KL, De George JJ \& Sheehan DM 1996 ICl 182,780 inhibits endogenous estrogendependent rat uterine growth and tamoxifen-induced developmental toxicity. Biology of Reproduction 54 160-167.

Calandra RS, Blaquier JA, del Castillo EJ \& Rivarola MA 1975 Androgen dependency of the androgen receptor in rat epididymis. Biochemical and Biophysical Research Communications 67 97-102.

Cho HW, Nie R, Carnes K, Zhou Q, Sharief NA \& Hess RA 2003 The antiestrogen $\mathrm{ICI} 182,780$ induces early effects on the adult male mouse reproductive tract and long-term decreased fertility without testicular atrophy. Reproductive Biology and Endocrinology 157.

Cotroneo MS, Wang J, Eltoum IA \& Lamartiniere CA 2001 Sex steroid receptor regulation by genistein in the prepubertal rat uterus. Molecular and Cellular Endocrinology 173 135-145.

Couse JF \& Korach KS 1998 Exploring the role of sex steroids through studies of receptor deficient mice. Journal of Molecular Medicine 76 497-511.

Danzo BJ, Cooper TG \& Orgebin-Crist MC 1977 Androgen binding protein $(\mathrm{ABP})$ in fluids collected from the rete testis and cauda epididymidis of sexually mature and immature rabbits and observations on morphological changes in the epididymis following ligation of the ductuli efferentes. Biology of Reproduction 17 64-77.

Derecka K, Zhang FP, Ziecik AJ \& Huhtaniemi I 1999 Ontogeny of $\mathrm{LH}$ receptor gene expression in the pig reproductive tract. Journal of Reproduction and Fertility 115 365-372.

Dohle GR, Smit M \& Weber RF 2003 Androgens and male fertility. World Journal of Urology 21 341-345.

Dukes M, Waterton JC \& Wakeling AE 1993 Antiuterotrophic effects of the pure antioestrogen ICl 182,780 in adult female monkeys (Macaca nemestrina): quantitative magnetic resonance imaging. Journal of Endocrinology 138 203-210.

Dupont S, Krust A, Gansmuller A, Dierich A, Chambon P \& Mark M 2000 Effect of single and compound knockouts of estrogen receptors $\alpha(E R \alpha)$ and $\beta(E R \beta)$ on mouse reproductive phenotypes. Development 127 4277-4291.

Ebling FJ, Brooks AN, Cronin AS, Ford H \& Kerr JB 2000 Estrogenic induction of spermatogenesis in the hypogonadal mouse. Endocrinology $1412861-2869$.

Eddy EM, Washburn TF, Bunch DO, Goulding EH, Gladen BC, Lubahn DB \& Korach KS 1996 Targeted disruption of the estrogen receptor gene in male mice causes alteration of spermatogenesis and infertility. Endocrinology 137 4796-4805.

Fan X \& Robaire B 1998 Orchidectomy induces a wave of apoptotic cell death in the epididymis. Endocrinology 139 2128-2136.

Fawcett DW \& Hoffer AP 1979 Failure of exogenous androgen to prevent regression of the initial segments of the rat epididymis after efferent duct ligation or orchidectomy. Biology of Reproduction 20 162-181. 
Fisher JS, Millar MR, Majdic G, Saunders PT, Fraser HM \& Sharpe RM 1997 Immunolocalisation of oestrogen receptor-alpha within the testis and excurrent ducts of the rat and marmoset monkey from perinatal life to adulthood. Journal of Endocrinology 153 485-495.

Fisher JS, Turner KJ, Brown D \& Sharpe RM 1999 Effect of neonatal exposure to estrogenic compounds on development of the excurrent ducts of the rat testis through puberty to adulthood. Environmental Health Perspectives 107 397-405.

Gonzalez-Cadavid N, Vernet D, Fuentes Navarro A, Rodriguez JA, Swerdloff RS \& Rajfer J 1993 Up-regulation of the levels of androgen receptor and its mRNA by androgens in smooth-muscle cells from rat penis. Molecular and Cellular Endocrinology 90 219-229.

Goyal HO \& Hrudka F 1980 The resorptive activity in the bull efferent ductules - a morphological and experimental study. Andrologia 12 401-404.

Goyal HO \& Williams CS 1988 The ductuli efferentes of the goat: a morphological study. Anatomical Record 220 58-67.

Goyal HO, Bartol FF, Wiley AA \& Neff CW 1997 Immunolocalization of receptors for androgen and estrogen in male caprine reproductive tissues: unique distribution of estrogen receptors in efferent ductule epithelium. Biology of Reproduction 56 90-101.

Goyal HO, Bartol FF, Wiley AA, Khalil MK, Williams CS \& Vig MM 1998 Regulation of androgen and estrogen receptors in male excurrent ducts of the goat: an immunohistochemical study. Anatomical Record 250 164-171.

Guo H, Cai CQ, Schroeder RA \& Kuo PC 2001 Osteopontin is a negative feedback regulator of nitric oxide synthesis in murine macrophages. Journal of Immunology 166 1079-1086.

Hansen LA, Clulow J \& Jones RC 1997 Perturbation of fluid reabsorption in the ductuli efferentes testis of the rat by testosterone propionate, $17 \beta$-oestradiol 3-benzoate, flutamide and tamoxifen. International Journal of Andrology 20 265-273.

Hess RA 2002 The efferent ductules: structure and functions. In The Epididymis: From Molecules to Clinical Practice, pp 49-80. Eds B Robaire \& B Hinton. New York: Kluwer Academic/Plenum.

Hess RA, Bunick D, Lee KH, Bahr J, Taylor JA, Korach KS \& Lubahn DB 1997a A role for oestrogens in the male reproductive system. Nature 390 509-512.

Hess RA, Gist DH, Bunick D, Lubahn DB, Farrell A, Bahr J, Cooke PS \& Greene GL 1997b Estrogen receptor (alpha and beta) expression in the excurrent ducts of the adult male rat reproductive tract. Journal of Andrology 18 602-611.

Hess RA, Bunick D \& Bahr J 2001 Oestrogen, its receptors and function in the male reproductive tract - a review. Molecular and Cellular Endocrinology 178 29-38.

Hess RA, Zhou Q \& Nie R 2002 The role of estrogens in the endocrine and paracrine regulation of the efferent ductules, epididymis and vas deferens. In The Epididymis: From Molecules to Clinical Practice, pp 317-338. Eds B Robaire \& B Hinton. New York: Kluwer Academic/Plenum.

Hess RA 2003 Estrogen in the adult male reproductive tract. A review. Reproductive Biology and Endocrinology 152.

Ilio KY \& Hess RA 1994 Structure and function of the ductuli efferentes: a review. Microscopic Research and Technology 29 $432-467$.

Jackson GL, Kuehl D \& Rhim TJ 1991 Testosterone inhibits gonadotropin-releasing hormone pulse frequency in the male sheep. Biology of Reproduction 45 188-194.

Janulis L, Hess RA, Bunick D, Nitta H, Janssen S, Asawa Y \& Bahr JM 1996 Mouse epididymal sperm contain active P450 aromatase which decreases as sperm traverse the epididymis. Journal of Andrology 17 111-116.

Janulis L, Bahr JM, Hess RA, Janssen S, Osawa Y \& Bunick D 1998 Rat testicular germ cells and epididymal sperm contain active P450 aromatase. Journal of Andrology 19 65-71.

Jeyaraj DA, Grossman G, Weaver C \& Petrusz P 2002 Dynamics of testicular germ cell proliferation in normal mice and transgenic mice overexpressing rat androgen-binding protein: a flow cytometric evaluation. Biology of Reproduction 66 877-885.

Krege JH, Hodgin JB, Couse JF, Enmark E, Warner M, Mahler JF, Sar M, Korach KS, Gustafsson JA \& Smithies O 1998 Generation and reproductive phenotypes of mice lacking estrogen receptor beta. PNAS 95 15677-15682.

Lauber AH, Mobbs CV, Muramatsu M \& Pfaff DW 1991 Estrogen receptor messenger RNA expression in rat hypothalamus as a function of genetic sex and estrogen dose. Endocrinology 129 $3180-3186$.

Lee KH, Hess RA, Bahr JM, Lubahn DB, Taylor J \& Bunick D 2000 Estrogen receptor alpha has a functional role in the mouse rete testis and efferent ductules. Biology of Reproduction 63 1873-1880.

Lee KH, Finnigan-Bunick C, Bahr J \& Bunick D 2001 Estrogen regulation of ion transporter messenger RNA levels in mouse efferent ductules are mediated differentially through estrogen receptor (ER) alpha and ERbeta. Biology of Reproduction 65 1534-1541.

Lubahn DB, Moyer JS, Golding TS, Couse JF, Korach KS \& Smithies O 1993 Alteration of reproductive function but not prenatal sexual development after insertional disruption of the mouse estrogen receptor gene. PNAS $9011162-11166$.

Lynch CS \& Story AJ 2000 Dihydrotestosterone and estrogen regulation of rat brain androgen-receptor immunoreactivity. Physiology and Behavior 69 445-453.

McKinnell C, Atanassova N, Williams K, Fisher JS, Walker M, Turner KJ, Saunders TK \& Sharpe RM 2001 Suppression of androgen action and the induction of gross abnormalities of the reproductive tract in male rats treated neonatally with diethylstilbestrol. Journal of Andrology 22 323-338.

Mansour MM, Machen MR, Tarleton BJ, Wiley AA, Wower J, Bartol FF \& Goyal HO 2001 Expression and molecular characterization of estrogen receptor alpha messenger RNA in male reproductive organs of adult goats. Biology of Reproduction 64 1432-1438.

al-Matubsi HY, Fairclough RJ \& Jenkin G 1998 Oestrogenic effects of ICI 182,780, a putative anti-oestrogen, on the secretion of oxytocin and prostaglandin F2 alpha during oestrous cycle in the intact ewe. Animal Reproduction Science 51 81-96.

Migliaccio A, Castoria G, Di Domenico M, de Falco A, Bilancio A, Lombardi M, Barone MV, Ametrano D, Zannini MS, Abbondanza C \& Auricchio F 2000 Steroid-induced androgen receptor-oestradiol receptor beta-src complex triggers prostate cancer cell proliferation. EMBO Journal 19 5406-5417.

Miller BG, Wild J \& Stone GM 1979 Effects of progesterone on the oestrogen-stimulated uterus: a comparative study of the mouse, guinea pig, rabbit and sheep. Australian Journal of Biological Sciences 32 549-560.

Morishima A, Grumbach MM, Simpson ER, Fisher C \& Qin K 1995 Aromatase deficiency in male and female siblings caused by a novel mutation and the physiological role of estrogens. Journal of Clinical Endocrinology and Metabolism 80 3689-3698.

Munell F, Suarez-Quian CA, Selva DM, Tirado OM \& Reventos J 2002 Androgen-binding protein and reproduction: where do we stand? Journal of Andrology 23 598-609.

Nie R, Zhou Q, Jassim E, Saunders PT \& Hess RA 2002 Differential expression of estrogen receptors alpha and beta in the reproductive tracts of adult male dogs and cats. Biology of Reproduction $\mathbf{6 6}$ 1161-1168.

Nielsen M, Bogh IB, Schmidt M \& Greve T 2001 Immunohistochemical localization of estrogen receptor-alpha in sex ducts and gonads of newborn piglets. Histochemistry and Cell Biology 115 521-526.

Ochiai I, Matsuda KI, Nishi M, Ozawa H \& Kawata M 2004 Imaging analysis of subcellular correlation of androgen receptor and estrogen receptor alpha in single living cells using GFP color variants. Molecular Endocrinology 18 26-42.

Oliveira CA, Carnes K, Franca LR \& Hess RA 2001 Infertility and testicular atrophy in the antiestrogen-treated adult male rat. Biology of Reproduction 65 913-920. 
Oliveira CA, Zhou Q, Carnes K, Nie R, Kuehl DE, Jackson GL, Franca LR, Nakai M \& Hess RA 2002 ER function in the adult male rat: short- and long-term effects of the antiestrogen $\mathrm{ICI}$ 182,780 on the testis and efferent ductules, without changes in testosterone. Endocrinology 143 2399-2409.

Oliveira C, Nie R, Carnes K, Franca LR, Prins GS, Saunders PTK \& Hess RA 2003 The antiestrogen ICI 182,780 decreases the expression of estrogen receptor-alpha but has no effect on estrogen receptor-beta and androgen receptor in rat efferent ductules. Reproductive Biology and Endocrinology 175.

Panet-Raymond V, Gottlieb B, Beitel LK, Pinsky L \& Trifiro MA 2000 Interactions between androgen and estrogen receptors and the effects on their transactivational properties. Molecular and Cellular Endocrinology 167 139-150.

Podesta EJ, Calandra RS, Rivarola MA \& Blaquier JA 1975 The effect of castration and testosterone replacement on specific proteins and androgen levels of the rat epididymis. Endocrinology 97 399-405.

Preisler-Mashek MT, Solodin N, Stark BL, Tyriver MK \& Alarid ET 2002 Ligand-specific regulation of proteasome-mediated proteolysis of estrogen receptor-alpha. American Journal of Physiology, Endocrinology and Metabolism 282 E891-E898.

Prins GS 1992 Neonatal estrogen exposure induces lobe-specific alterations in adult rat prostate androgen receptor expression. Endocrinology $1303703-3714$.

Prins GS \& Birch L 1997 Neonatal estrogen exposure up-regulates estrogen receptor expression in the developing and adult rat prostate lobes. Endocrinology 138 1801-1809.

Prins G, Birch L \& Greene G 1991 Androgen receptor localization in different cell types of the adult rat prostate. Endocrinology 129 3187-3199.

Prins GS, Marmer M, Woodham C, Chang W, Kuiper G, Gustafsson JA \& Birch L 1998 Estrogen receptor-beta messenger ribonucleic acid ontogeny in the prostate of normal and neonatally estrogenized rats. Endocrinology 139 874-883.

Prins GS, Birch L, Couse JF, Choi I, Katzenellenbogen B \& Korach KS 2001 Estrogen imprinting of the developing prostate gland is mediated through stromal estrogen receptor alpha: studies with alphaERKO and betaERKO mice. Cancer Research 61 6089-6097.

Quarmby VE, Yarbrough WG, Lubahn DB, French FS \& Wilson EM 1990 Autologous down-regulation of androgen receptor messenger ribonucleic acid. Molecular Endocrinology 4 22-28.

Rivas A, Fisher JS, Mckinnell C, Atanassova N \& Sharpe RM 2002 Induction of reproductive tract developmental abnormalities in the male rat by lowering androgen production or action in combination with a low dose of diethylstilbestrol: evidence for importance of the androgen-estrogen balance. Endocrinology 143 4797-4808.

Rivas A, Mckinnell C, Fisher JS, Atanassova N, Williams K \& Sharpe RM 2003 Neonatal co-administration of testosterone with diethylstilbestrol prevents diethylstilbestrol induction of most reproductive tract abnormalities in male rats. Journal of Andrology 24 557-567.

Robaire B \& Viger RS 1995 Regulation of epididymal epithelial cell functions. Biology of Reproduction 52 226-236.

Robertson KM, O'Donnell L, Jones ME, Meachem SJ, Boon WC, Fisher CR, Graves KH, McLachlan RI \& Simpson ER 1999 Impairment of spermatogenesis in mice lacking a functional aromatase (cyp 19) gene. PNAS 96 7986-7991.

Roselli CE \& Resko JA 1984 Androgens regulate brain aromatase activity in adult male rats through a receptor mechanism. Endocrinology $1142183-2189$.

Roselli CE, West NB \& Brenner RM 1991 Androgen receptor and 5 alpha-reductase activity in the ductuli efferentes and epididymis of adult rhesus macaques. Biology of Reproduction 44 739-745.

Rosenfeld CS, Ganjam VK, Taylor JA, Yuan X, Stiehr JR, Hardy MP \& Lubahn DB 1998 Transcription and translation of estrogen receptor-beta in the male reproductive tract of estrogen receptor-alpha knock-out and wild-type mice. Endocrinology 139 2982-2987.

Rosner W, Hryb DJ, Khan MS, Nakhla AM \& Romas NA 1998 Androgens, estrogens, and second messengers. Steroids 63 278-281.
Sar M, Lubahn DB, French FS \& Wilson EM 1990 Immunohistochemical localization of the androgen receptor in rat and human tissues. Endocrinology 127 3180-3186.

Saunders PT, Millar MR, Williams K, Macpherson S, Harkiss D, Anderson RA, Orr B, Groome NP, Scobie G \& Fraser HM 2000 Differential expression of estrogen receptor-alpha and -beta and androgen receptor in the ovaries of marmosets and humans. Biology of Reproduction 63 1098-1105.

Saunders PT, Sharpe RM, Williams K, Macpherson S, Urquart H, Irvine DS \& Millar MR 2001 Differential expression of oestrogen receptor alpha and beta proteins in the testes and male reproductive system of human and non-human primates. Molecular Human Reproduction 7 227-236.

Schleicher G, Drews U, Stumpf WE \& Sar M 1984 Differential distribution of dihydrotestosterone and estradiol binding sites in the epididymis of the mouse. An autoradiographic study. Histochemistry 81 139-147.

Shughrue PJ, Lane MV, Scrimo PJ \& Merchenthaler I 1998 Comparative distribution of estrogen receptor-alpha (ER-alpha) and -beta (ER-beta) mRNA in the rat pituitary, gonad, and reproductive tract. Steroids 63 498-504.

Smith EP, Boyd J, Frank GR, Takahashi H, Cohen RM, Specker B, Williams TC, Lubahn DB \& Korach KS 1994 Estrogen resistance caused by a mutation in the estrogen-receptor gene in a man. New England Journal of Medicine 331 1056-1061.

Stone GM, McCaffery C \& Miller BG 1982 Effects of progesterone on nuclear and cytosol steroid receptor levels in the oestrogen-stimulated uterus: comparison of the sheep and mouse. Australian Journal of Biological Sciences 35 403-415.

Tarleton BJ, Wiley AA \& Bartol FF 1999 Endometrial development and adenogenesis in the neonatal pig: effects of estradiol valerate and the antiestrogen ICl 182,780. Biology of Reproduction 61 $253-263$.

Tena-Sempere M, Navarro J, Pinilla L, Gonzalez LC, Huhtaniemi I \& Aguilar E 2000 Neonatal exposure to estrogen differentially alters estrogen receptor alpha and beta mRNA expression in rat testis during postnatal development. Journal of Endocrinology $\mathbf{1 6 5}$ 345-357.

Thomas EJ, Walton PL, Thomas NM \& Dowsett M 1994 The effects of $\mathrm{ICl} 182,780$, a pure anti-oestrogen, on the hypothalamic-pituitary-gonadal axis and on endometrial proliferation in pre-menopausal women. Human Reproduction 9 1991-1996.

Tirado OM, Selva DM, Toran N, Suarez-Quian CA, Jansen $M$, McDonnell DP, Reventos J \& Munell F 2004 Increased expression of estrogen receptor beta in pachytene spermatocytes after shortterm methoxyacetic acid administration. Journal of Andrology $\mathbf{2 5}$ 84-94.

Turner KJ, Morley M, Atanassova N, Swanston ID \& Sharpe RM 2000 Effect of chronic administration of an aromatase inhibitor to adult male rats on pituitary and testicular function and fertility. Journal of Endocrinology 164 225-238.

Turner KJ, Morley M, MacPherson S, Millar MR, Wilson JA, Sharpe RM \& Saunders PT 2001 Modulation of gene expression by androgen and oestrogens in the testis and prostate of the adult rat following androgen withdrawal. Molecular and Cellular Endocrinology $17873-87$.

Vreeburg JTM 1975 Distribution of testosterone and $5 \alpha$-dihydrotestosterone in rat epididymis and their concentrations in efferent duct fluid. Journal of Endocrinology 67 203-210.

Wakeling AE, Bowler J, Wakeling AE, Dukes M \& Bowler J 1991 Development of novel oestrogen-receptor antagonists. A potent, specific, pure antiestrogen with clinical potential. Biochemical Society Transactions 19 899-901.

Wiszniewska B 2002 Primary culture of the rat epididymal epithelial cells as a source of oestrogen. Andrologia 34 180-187.

Woodham C, Birch L \& Prins GS 2003 Neonatal estrogen down-regulates prostatic androgen receptor through a proteosomemediated protein degradation pathway. Endocrinology 144 $4841-4850$. 
Yeap BB, Krueger RG \& Leedman PJ 1999 Differential posttranscriptional regulation of androgen receptor gene expression by androgen in prostate and breast cancer cells. Endocrinology 140 $3282-3291$.

Yeh S, Miyamoto H, Shima H \& Chang C 1998 From estrogen to androgen receptor: a new pathway for sex hormones in prostate. PNAS 95 5527-5532.

Zhou Q, Clarke L, Nie R, Carnes K, Lai LW, Lien YH, Verkman A, Lubahn D, Fisher JS, Katzenellenbogen BS \& Hess RA 2001a Estrogen action and male fertility: roles of the sodium/hydrogen exchanger-3 and fluid reabsorption in reproductive tract function. PNAS $9814132-14137$.

Zhou S, Zilberman Y, Wassermann K, Bain SD, Sadovsky Y \& Gazit D 2001b Estrogen modulates estrogen receptor alpha and beta expression, osteogenic activity, and apoptosis in mesenchymal stem cells (MSCS) of osteoporotic mice. Journal of Cellular Biochemistry. Supplement 36 144-155.

Zhou Q, Nie R, Prins GS, Saunders PT, Katzenellenbogen BS \& Hess RA 2002 Localization of androgen and estrogen receptors in adult male mouse reproductive tract. Journal of Andrology $\mathbf{2 3}$ $870-881$.

Zhu LJ, Hardy MP, Inigo IV, Huhtaniemi I, Bardin CW \& MooYoung AJ 2000 Effects of androgen on androgen receptor expression in rat testicular and epididymal cells: a quantitative immunohistochemical study. Biology of Reproduction $\mathbf{6 3}$ 368-376.

Zou K \& Ing NH 1998 Oestradiol up-regulates oestrogen receptor, cyclophilin, and glyceraldehyde phosphate dehydrogenase mRNA concentrations in endometrium, but down-regulates them in liver. Journal of Steroid Biochemistry and Molecular Biology 64 $231-237$.

Received 9 December 2003

First decision 11 February 2004

Accepted 9 March 2004 